\title{
Pengaruh Variabel Sosial Ekonomi Terhadap Perkawinan Usia Anak pada Wanita di Indonesia Tahun 2017
}

\author{
ADE WIDIANTARA ${ }^{1}$, RISNI JULAENI YUHAN ${ }^{2}$ \\ Politeknik Statistika STIS Jakarta \\ email: 1ade.widiantara@bps.go.id, 2risnij@stis.ac.id
}

\begin{abstract}
ABSTRAK
Perkawinan anak di Indonesia saat ini berada pada kondisi yang cukup mengkhawatirkan. Diketahui terdapat 20 provinsi dengan angka pravelensi perkawinan anak di atas angka nasional pada tahun 2015. Perampasan hak dasar anak perempuan yang disebabkan menikah sebelum umur 15-18 tahun berdampak pada meningkatkan angka kematian ibu, angka kematian bayi, melahirkan bayi malnutrisi, menimbulkan berbagai persoalan rumah tangga seperti pertengkaran, percekcokan, konflik berkepanjangan, hingga mengakibatkan perceraian. Disamping itu, permasalahan tersebut tentunya akan membawa pada angka ketergantungan yang tinggi. Dalam upaya menekan permasalahan perkawinan usia anak, maka menjadi penting untuk mengetahui variabel sosial ekonomi yang mempengaruhi usia kawin pertama bagi perempuan yang melakukan perkawinan usia anak. Oleh karena itu dalam penelitian ini akan dikaji mengenai kecenderungan variabel sosial dan ekonomi yang berpengaruh terhadap perkawinan usia anak pada wanita pernah kawin usia 15-24 tahun di Indonesia dengan menggunakan analisis regresi logistik biner. Hasil penelitian menunjukkan bahwa terdapat satu dari empat wanita pernah kawin 15-24 tahun melakukan perkawinan pada usia anak. Berdasarkan hasil analisis regresi logistik yaitu variabel daerah tempat tinggal, status bekerja dan jenis pekerjaan wanita, tingkat pendidikan wanita, tingkat pendidikan orang tua, usia kawin pertama orang tua dan status kemiskinan berpengaruh signifikan terhadap terjadinya perkawinan anak pada wanita pernah kawin usia 15-24 tahun di Indonesia tahun 2017.
\end{abstract}

Kata kunci: perkawinan anak, wanita pernah kawin usia 15-24 tahun, sosial ekonomi, regresi logistik

\begin{abstract}
Child marriage in Indonesia is currently at an alarming condition. It is known that there are 20 provinces with child marriage pravain rates above the national figure in 2015. The deprivation of the basic rights of girls who are married before the age of 15-18 years has an impact on increasing maternal mortality, infant mortality rate, giving birth to malnourished infants, stairs such as quarrels, arguments, prolonged conflicts, leading to divorce. In addition, the problem will certainly lead to high dependency ratio. In an effort to suppress marriage issues of childhood, it becomes important to know the socioeconomic factors affecting the first marriage age for women who marry the age of the child. Therefore in this study will be studied about the tendency of social and economic variables that affect the marriage of children aged in married women aged 15-24 years in Indonesia by using binary logistic regression analysis. The results showed that 1 in 4 women ever married 1524 years of marriage at the age of the child. Based on the result of logistic regression analysis that is domicile domicile of residence, work status and type of work of woman, level of education of woman, parent education level, age of first marriage of parent and poverty status have significant effect to the marriage of child to woman ever married age 15-24 year in Indonesia in 2017
\end{abstract}

Keywords: Child marriage, married women aged 15-24 years, social economy, logistic regression

\section{PENDAHULUAN}

Menurut UU Nomor 1 Tahun 1974, perkawinan ialah ikatan lahir batin antara seorang pria dengan seorang wanita sebagai suami istri dengan tujuan membentuk keluarga (rumah tangga) yang bahagia dan kekal berdasarkan Ketuhanan Yang Maha Esa. Perkawinan merupakan 


\section{Ade Widiantara dkk.}

ikatan sakral antara pasangan pria dan wanita yang diakui secara sosial untuk membangun keluarga, melegalkan hubungan seksual, melegitimasi dan membesarkan anak, membagi peran antar pasangan. Perkawinan dimaksudkan untuk membina hubungan yang langgeng antara kedua pasangan, sehingga dalam menjalani perkawinan dibutuhkan kedewasaan dan tanggung jawab baik secara fisik maupun mental. Oleh karena itu, dibutuhkan peraturan undangundang mengatur batasan umur pernikahan. Namun pada kenyataannya masih banyak dijumpai perkawinan yang dilakukan dibawah batasan umur perkawinan dan usia anak atau dikenal sebagai perkawinan usia anak.

Adapun definisi anak menurut UU Nomor 35 Tahun 2014 adalah seseorang yang belum berusia 18 tahun. Maka, yang dimaksud dengan perkawinan usia anak ialah perkawinan yang dilakukan melalui hukum perdata, agama atau adat, dan dengan atau tanpa pencatatan atau persetujuan resmi dimana salah satu atau kedua pasangan adalah anak berusia di bawah 18 tahun (BPS dan UNICEF, 2016)

Terdapat sekitar 142 juta anak perempuan di dunia melakukan perkawinan sebelum masa dewasanya. Indonesia berada pada peringkat ke tujuh di dunia dengan jumlah perkawinan usia anak tertinggi pada tahun 2013, yakni terdapat 458 ribu wanita pernah kawin yang berusia 20 hingga 24 tahun dan melangsungkan pernikahan sebelum usia 15 tahun (Council of Foreign Relations 2015). Di ASEAN, Indonesia juga menempati peringkat tertinggi kedua setelah Kamboja

Berdasarkan data susenas 2008 prevalensi perkawinan usia anak di Indonesia ialah sebesar 27,4 persen, dan pada tahun 2015 prevalensi perkawinan usia anak di Indonesia sebesar 22,82 persen. Artinya, Dalam kurun waktu 7 tahun prevalensi perkawinan usia anak di Indonesia hanya mengalami penurunan sekitar 4,6 persen. Hal ini menunjukkan pengentasan perkawinan anak di Indonesia mengalami kemunduran. Jika terus dibiarkan, maka tujuan kelima SDGs Indonesia terkait penghapusan (target nol) perkawinan usia anak di Indonesia pada tahun 2030 terancam gagal. Berdasarkan data susenas tahun 2015, terdapat 20 provinsi dengan angka pravelensi perkawinan anak di atas angka nasional yang tersebar dari Sumatera hingga Papua.

Banyaknya jumlah provinsi yang memiliki prevalensi perkawinan anak yang tinggi telah menimbulkan masalah yang kompleks dalam berbagai aspek kehidupan, terutama pada masalah kependudukan. Perkawinan usia anak akan meningkatkan pertumbuhan penduduk, karena secara langsung berkaitan dengan kelahiran. Perempuan yang melakukan perkawinan pada usia anak memiliki durasi atau kemungkinan untuk hamil lebih lama dari pada mereka yang melakukan perkawinan pada usia dewasa. Permasalahan tentang perkawinan anak akan membawa pada angka beban ketergantungan (dependency ratio) yang besar. Wanita yang melakukan perkawinan di usia muda akan lebih cepat untuk memiliki anak sehingga harus memikul tanggungan dari penduduk berusia lanjut dan anak-anak. Diketahui pada tahun 2015 Indonesia memiliki nilai dependency ratio sebesar 48,6. Artinya pada tiap 100 penduduk harus menanggung 49 penduduk yang tidak produktif.

Perkawinan yang dilakukan pada usia yang terlalu muda juga akan meningkatkan angka kematian ibu (359/100.000 kelahiran), angka kematian bayi (32/1000 kelahiran), serta melahirkan bayi malnutrisi (4,5 juta/tahun) yang mengakibatkan berkurangnya generasi bagi bangsa di masa depan (SDKI, 2012). Anak dari ibu yang sangat muda dan sangat tua saat melahirkan memiliki risiko kematian yang tinggi. Angka kematian anak yang tinggi pada wanita yang melahirkan diumur yang sangat muda dan tua kemungkinan berhubungan dengan faktor biologis yang mengakibatkan terjadinya komplikasi selama kehamilan dan saat persalinan.

Disamping itu, perkawinan pada usia anak juga bisa menimbulkan berbagai persoalan dalam rumah tangga seperti pertengkaran, percekcokan, dan konflik berkepanjangan, hingga dapat mengakibatkan perceraian. Data susenas tahun 2015 menunjukkan bahwa tingkat perceraian pada perempuan usia 20-24 yang menikah sebelum usia 18 tahun sebesar 4,53 persen, lebih tinggi dibandingkan mereka yang menikah pada usia 18 tahun ke atas yaitu 3,02 persen.

Dalam upaya menekan permasalahan perkawinan usia anak, maka menjadi penting untuk mengetahui variabel sosial ekonomi yang mempengaruhi perkawinan usia anak. Berdasarkan penelitian sebelumnya yang berkaitan dengan latar belakang masalah dalam penelitian ini, Minja Kim Choe et al. (2001) menemukan bahwa faktor-faktor yang bisa memengaruhi wanita untuk melakukan pernikahan dini di Indonesia dan Nepal diantaranya usia, pendidikan wanita, asal daerah, pendidikan ayah dan pendidikan ibu. Kemudian dalam studi literatur 
yang dilakukan Plan Internasional Australia (2014) disebutkan bahwa ketimpangan gender, budaya, kepercayaan, kemiskinan, krisis, dan peran hukum berpengaruh terhadap keputusan keberlangsungan perkawinan anak. Selain itu, Masthuriyah Sa'dan (2016) menyatakan bahwa beberapa alasan seseorang melakukan pernikahan di usia muda yaitu adanya hukum islam dan hukum adat, kepentingan yang bersifat ekonomi, rendahnya tingkat Pendidikan, dan budaya patriarki. Faktor lainnya yang diungkapkan Dewi Candraningrum et al. (2016) dalam penelitiannya bahwa perkawinan di usia anak dapat terjadi disebabkan motif agama untuk menghindari zina, Pendidikan anak yang rendah, ekonomi keluarga, serta kurang nya pengetahuan terhadap system reproduksi. Sedangkan Aulia Imawati (2011) menyatakan bahwa faktor sosial demografi seperti usia kepala rumah tangga, pendidikan tertinggi yang pernah atau sedang diduduki, jjazah kepala rumah tangga, lokasi tempat tinggal, dan letak geografis dapat mempengaruhi usia perkawinan di Provinsi Jawa Timur.

Agar penelitian ini dapat dilakukan lebih fokus, terarah dan mendalam, maka permasalahan penelitian yang diangkat perlu dibatasi objek dan variabelnya. Objek yang diteliti pada penelitian ini yaitu wanita usia 15-24 tahun berstatus pernah kawin termasuk cerai hidup ataupun cerai mati dan variabel yang dibatasi berkaitan dengan tingkat pendidikan wanita, status dan jenis pekerjaan wanita, tingkat pendidikan orang tua, usia kawin pertama orang tua, klasifikasi daerah tempat tinggal dan status kemiskinan terhadap perkawinan usia anak di Indonesia tahun 2017.

Berdasarkan uraian mengenai masalah tersebut, maka tujuan yang hendak dicapai peneliti dalam penelitian ini yaitu memberikan gambaran karakteristik wanita pernah kawin usia 1524 tahun yang melakukan perkawinan pertama pada usia anak, menganalisis variabel sosial ekonomi yang berpengaruh terhadap perkawinan usia anak pada wanita pernah kawin usia 1524 tahun di Indonesia tahun 2017 serta menganalisis besarnya kecenderungan variabelvariabel yang memengaruhi wanita pernah kawin usia 15-24 tahun yang melakukan perkawinan pertama pada usia anak di Indonesia.

\section{METODOLOGI}

\section{Metode Pengumpulan Data}

Data yang digunakan dalam penelitian ini berupa data mentah dari Survei Sosial dan Ekonomi Nasional (Susenas) Kor bulan Maret tahun 2017. Pengumpulan data susenas Kor 2017 ini dilaksanakan pada bulan maret 2017 dengan metode wawancara langsung antara petugas dengan responden. Data yang dikumpulkan susenas berkaitan dengan kondisi sosial ekonomi masyarakat, meliputi kondisi kesehatan, pendidikan, fertilitas, Keluarga Berencana, perumahan dan kondisi sosial ekonomi lainnya. Penelitian ini menggunakan variabel yang diperoleh dari pertanyaan-pertanyaan yang terdapat pada kuesioner susenas kor 2017 yaitu sebagai berikut:

1. Variabel pendidikan tertinggi diperoleh dari pertanyaan R515.

2. Variabel status dan jenis pekerjaan wanita diperoleh dari pertanyaan R801, 802, 803, dan 805.

3. Variabel usia kawin pertama diperoleh dari pertanyaan R409.

4. Variabel domisili tempat tinggal diperoleh dari pertanyaan R105.

5. Variabel status kemiskinan diperoleh dari variabel pendapatan yang dilampirkan bersamaan pada permintaan raw data Susenas KOR 2017.

Susenas 2017 dilaksanakan diseluruh provinsi di Indonesia dengan jumlah sampel berjumlah 300.000 rumah tangga yang tersebar di 34 provinsi dan 514 kabupaten/kota. Sampel susenas tidak mencakup rumah tangga yang terdapat di blok sensus khusus atau rumah tangga khusus seperti asrama, penjara, pondok pesantren dan lain sebagainya. Melainkan rumah tangga yang terdapat di blok sensus biasa dan di record menggunakan kuesioner VSEN2017.K Sebanyak 300.000 target rumah tangga sampel, hanya 297.276 rumah tangga sampel yang dinyatakan bersih dan dapat diolah. Namun dalam penelitian ini, hanya sebanyak 6686 wanita pernah kawin (WPK) berusia 15-24 tahun dan berstatus sebagai anak dalam rumah tangga tersebut yang dijadikan sampel penelitian. 


\section{Ade Widiantara dkk.}

\section{Metode analisis}

Variabel tak bebas yang digunakan dalam penelitian ini berbentuk biner yang dikategorikan berupa wanita yang melangsungkan pernikahan pertama kali pada usia anak ( $<18$ tahun) dan wanita yang melangsungkan pernikahan pertama kali diatas usia anak ( $\geq 18$ tahun). Sedangkan Variabel bebasnya meliputi:

- Daerah tempat tinggal (X1).

- Status dan jenis pekerjaan wanita (X2)

- $\quad$ Status kemiskinan (X3)

- Usia kawin pertama (UKP) orang tua (X4)

- Pendidikan tertinggi wanita pernah kawin (X5)

- $\quad$ Tingkat pendidikan terakhir orang tua (X6)

Metode analisis yang digunakan dalam penelitian ini terbagi menjadi dua, yaitu analisis deskriptif dan analisis inferensia. Analisis deskriptif bertujuan untuk memberikan gambaran umum mengenai karakteristik status perkawinan anak pada WPK usia 15-24 tahun di Indonesia yang kemudian disajikan dalam bentuk tabel, grafik maupun diagram agar lebih mudah dipahami oleh pengguna. Analisis inferensia yang digunakan dalam penelitian ini ialah analisis regresi logistik biner, untuk mendapatkan model dari variabel-variabel yang berpengaruh terhadap status perkawinan anak. Penelitian ini menggunakan tingkat signifikansi 5 persen dengan metode backward wald secara simultan dan parsial. Bentuk umum persamaan regresi logistik sebagai berikut.

$g(x)=\ln \left[\frac{\pi(\mathrm{x})}{1-\pi(x))}\right]=\beta_{0}+\beta_{1} x_{1}+\beta_{2} x_{2}+\cdots+\beta_{p} x_{p}$

Uji simultan dilakukan untuk mengetahui pengaruh seluruh variabel bebas secara bersamasama terhadap status perkawinan usia anak. Hipotesis dan statistik uji dari uji simultan yaitu:

Ho : $\beta_{1}=\beta_{2}=\beta_{3} \ldots=\beta_{p}=0$

$\mathrm{H} 1$ : minimal terdapat satu nilai $\beta_{p} \neq 0$

$G=-2 \ln \left(\frac{l_{0}}{l_{1}}\right)$

Nilai dari statistik uji $G$ mengikuti sebaran dari chi-square, dimana derajat bebas nya berupa $p$ yakni jumlah seluruh variabel bebas yang terdapat didalam model. Keputusan tolak Ho jika nilai dari $G>\chi_{\left(\kappa_{p}\right)}^{2}$ atau disaat $p$-value $<$ a.

Sedangkan uji parsial digunakan untuk menguji pengaruh tiap-tiap variabel bebas terhadap status perkawinan usia anak. Hipotesis dan statistik uji dari uji parsial sebagai berikut:

Ho $: \beta_{j}=0$
$\mathrm{H} 1: \beta_{j} \neq 0$
$W=\left(\frac{\hat{\beta}_{j}}{\operatorname{Se}\left(\hat{\beta}_{j}\right)}\right)^{2}$

Nilai dari statistik uji $W$ mengikuti sebaran dari chi-square, dimana derajat bebasnya 1 . Keputusan tolak Ho jika nilai dari $W>\chi_{\left(\kappa_{1} 1\right)}^{2}$ atau disaat $p$-value $<a$. Artinya, variabel bebas ke-j berpengaruh signifikan terhadap variabel tak bebas nya.

Selain itu, uji kesesuaian model menggunakan statistik uji Hosmer and Lemeshow juga dilakukan untuk mengetahui apakah model layak atau sesuai dalam menjelaskan variabel respons. Berikut hipotesis dan statistik uji dari hosmer and lemeshow test.

Ho: Model sudah sesuai dengan data yang digunakan (model Fit)

H1: Model tidak sesuai dengan data yang digunakan (model tidak Fit) 
$\hat{C}=\sum_{k=1}^{g} \frac{\left(O_{k}-n_{k}^{\prime} \bar{\pi}_{k}\right)^{2}}{n_{k}^{\prime} \bar{\pi}_{k}\left(1-\bar{\pi}_{k}\right)}$

Keputusan tolak Ho jika nilai dari $\hat{C}>\chi_{(\alpha, g-2)}^{2}$ atau disaat $p$-value $<a$. Kemudian menghitung nilai odds ratio dari masing-masing variabel yang signifikan untuk mengetahui risiko kecenderungan dalam mengalami kejadian antara suatu kategori dengan kategori referensi pada setiap variabel bebas.

\section{HASIL DAN PEMBAHASAN}

\section{Analisis Deskriptif}

Berdasarkan hasil pada penelitian ini, lebih seperempat dari seluruh WPK berusia 15-24 tahun menikah pada usia anak. Artinya, terdapat satu dari empat wanita pernah kawin usia 15-24 tahun yang melangsungkan pernikahan dibawah usia 18 tahun.

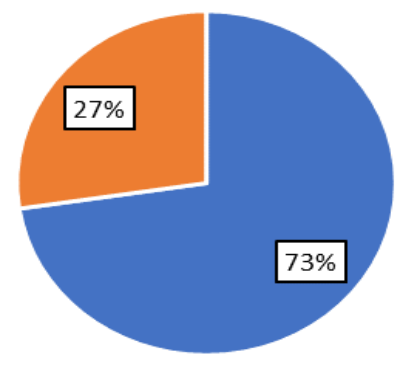

- Menikah pada usia $>=18$ tahun

- Menikah pada usia anak( $<18$ tahun)

Sumber: SUSENAS 2017 (diolah)

Gambar 1. Distribusi Usia Kawin Pertama wanita kawin usia 15-24 tahun 2017

Tabel 1. Persentase WPK 15-24 tahun di Indonesia tahun 2017 berdasarkan karakteristiknya.

\begin{tabular}{|c|c|c|}
\hline Variabel & Kategori & Persentase \\
\hline$(1)$ & $(2)$ & (3) \\
\hline \multirow[t]{2}{*}{ Daerah tempat tinggal } & Perkotaan & 39,72 \\
\hline & perdesaan & 60,28 \\
\hline \multirow[t]{8}{*}{ Pendidikan WPK } & 0. Tidak bersekolah & 0,30 \\
\hline & 1. Tidak Lulus SD & 6,28 \\
\hline & 2. Lulus SD & 16,43 \\
\hline & 3. Tidak Lulus SMP & 5,18 \\
\hline & 4. Lulus SMP & 28,72 \\
\hline & 5. Tidak Lulus SMA & 7,27 \\
\hline & 6. Lulus SMA & 26,49 \\
\hline & 7. > SMA & 9,33 \\
\hline \multirow{4}{*}{$\begin{array}{l}\text { Jenis pendidikan tertinggi yang } \\
\text { pernah/sedang diduduki orang tua }\end{array}$} & 0. Tidak Bersekolah & 7,89 \\
\hline & 1. SD & 62,12 \\
\hline & 2. SMP & 17,49 \\
\hline & 3. $\geq$ SMA & 12,49 \\
\hline \multirow{2}{*}{ Status Kemiskinan } & 0. Miskin & 14,94 \\
\hline & 1. Tidak Miskin & 85,06 \\
\hline \multirow{2}{*}{ Usia kawin pertama orang tua } & $0 .<18$ tahun (Usia anak) & 10,8 \\
\hline & 1. $\geq 18$ tahun & 89,2 \\
\hline \multirow{3}{*}{ Status \& Jenis Pekerjaan WPK } & 0. Tidak memiliki pekerjaan & 70,32 \\
\hline & 1. Informal & 12,82 \\
\hline & 2. Formal & 16,87 \\
\hline
\end{tabular}




\section{Ade Widiantara dkk.}

Berdasarkan Tabel 1. Distribusi WPK usia 15-24 tahun dominan berdomisili di daerah perdesaan. Terlihat wanita yang tinggal didaerah perkotaan lebih sedikit sepertiga dari pada yang tinggal di pedesaan. Mereka yang lulus pendidikannya juga lebih banyak dibandingkan yang putus sekolah atau tidak bersekolah. Lebih dari setengah WPK berusia 15-24 tahun lulus sekolah menengah. Sedangkan yang tidak bersekolah hanya mencapai 0,3 persen. Distribusi pendidikan orang tua dari WPK usia 15-24 tahun di dominasi oleh mereka yang mengenyam pendidikan dibangku sederajat SD yaitu sebesar 62,12 persen. sedangkan persentase terkecil ditunjukkan oleh penduduk WPK berusia 15 - 24 tahun yang orang tuanya tidak bersekolah atau tidak pernah mendapatkan pendidikan yaitu sebesar 7,89 persen. Persentase WPK berusia $15-24$ tahun di Indonesia yang usia kawin pertama orang tua nya lebih atau sama dengan 18 tahun jauh lebih banyak dibandingkan wanita yang usia kawin pertama orang tuanya dibawah 18 tahun. Sebesar 89,2 persen wanita memiliki orang tua yang menikah diatas usia anak ( $\geq 18$ tahun). Sedangkan 10,8 persen penduduk WPK berusia $15-24$ tahun memiliki orang tua yang menikah di usia kurang dari 18 tahun.

Berdasarkan Tabel 1. juga dapat dilihat bahwa distribusi WPK 15-24 tahun yang tidak bekerja jauh lebih besar dari pada mereka yang bekerja. Terdapat sebesar 70,32 persen WPK usia 1524 tahun yang tidak bekerja dan wanita yang bekerja pada sektor formal sebesar 16,87 persen. Sedangkan distribusi dengan jumlah terkecil ialah mereka yang bekerja pada sektor informal yakni sebesar 12,82 persen. Sementara itu, persentase WPK usia 15-24 tahun di Indonesia yang status ekonomi keluarganya tidak miskin sebesar 85,06 persen. Hasil tersebut menunjukkan bahwa jumlah wanita yang status ekonomi miskin jauh lebih sedikit dibandingkan dengan wanita yang status ekonominya tidak miskin.

Tabel 2. Persentase perkawinan usia anak pada WPK 15-24 tahun di Indonesia tahun 2017 berdasarkan karakteristiknya.

\begin{tabular}{|c|c|c|c|}
\hline \multirow{2}{*}{ Variabel } & \multirow{2}{*}{ Kategori } & \multicolumn{2}{|c|}{ Perkawinan anak (\%) } \\
\hline & & $\mathrm{Ya}$ & Tidak \\
\hline$(1)$ & $(2)$ & (3) & $(4)$ \\
\hline \multirow{2}{*}{ Daerah tempat tinggal } & 0. Perkotaan & 23,11 & 76,89 \\
\hline & 1. Perdesaan & 30,19 & 69,81 \\
\hline \multirow{8}{*}{ Pendidikan WPK } & 0. Tidak bersekolah & 45,7 & 54,35 \\
\hline & 1. Tidak Lulus SD & 36,3 & 63,69 \\
\hline & 2. Lulus SD & 37,9 & 62,12 \\
\hline & 3. Tidak Lulus SMP & 46,4 & 53,56 \\
\hline & 4. Lulus SMP & 33,8 & 66,22 \\
\hline & 5. Tidak Lulus SMA & 42,3 & 57,66 \\
\hline & 6. Lulus SMA & 8,6 & 91,41 \\
\hline & 7. > SMA & 13,7 & 86,35 \\
\hline \multirow{4}{*}{$\begin{array}{l}\text { Jenis } \quad \text { pendidikan } \\
\text { tertinggi } \\
\text { pernah/sedang } \\
\text { diduduki Orang tua }\end{array}$} & 0. Tidak Bersekolah & 38,30 & 61,70 \\
\hline & 1. SD & 27,91 & 72,09 \\
\hline & 2. SMP & 25,86 & 74,14 \\
\hline & 3. $\geq$ SMA & 19,97 & 80,03 \\
\hline \multirow{2}{*}{ Status Kemiskinan } & 0. Miskin & 34,22 & 65,78 \\
\hline & 1. Tidak Miskin & 26,17 & 73,83 \\
\hline \multirow{2}{*}{$\begin{array}{l}\text { Usia kawin pertama } \\
\text { orang tua }\end{array}$} & $0 .<18$ tahun (Usia anak) & 35,83 & 64,17 \\
\hline & 1. $\geq 18$ tahun & 26,35 & 73,65 \\
\hline \multirow{3}{*}{$\begin{array}{ll}\text { Status } & \text { \&Jenis } \\
\text { Pekerjaan WPK } & \end{array}$} & 0. Tidak memiliki pekerjaan & 28,56 & 71,44 \\
\hline & 1. Informal & 31,20 & 68,80 \\
\hline & 2. Formal & 19,56 & 80,44 \\
\hline
\end{tabular}

Berdasarkan Tabel 2. diantara WPK berusia 15-24 tahun yang melakukan perkawinan pada usia anak, mereka yang berdomisili di daerah pedesaan lebih tinggi dibandingkan perkotaan dan umumnya terjadi pada keluarga yang miskin. Setidaknya terdapat 34,22 persen WPK berusia 15-24 tahun melakukan perkawinan pada usia anak yang berasal dari keluarga miskin. Persentase perkawinan anak pada WPK berusia 15-24 tahun yang putus sekolah dan 
atau tidak bersekolah lebih tinggi dari pada mereka yang menamatkan sekolahnya. Distribusi tertinggi WPK berusia 15-24 tahun yang melakukan perkawinan pada usia anak berada pada tingkat pendidikan tidak lulus SMP. Begitu pula WPK yang bekerja pada sektor informal memiliki persentase perkawinan anak lebih tinggi dari pada mereka yang bekerja di sektor formal dan atau tidak memiliki pekerjaan. Kasus perkawinan anak juga banyak terjadi pada WPK yang usia kawin pertama orang tuanya pada usia anak dan berpendidikan rendah. Orang tua yang tidak bersekolah kemudian menikahkan anaknya sebelum usia 18 tahun lebih banyak dari pada orang tua yang bersekolah

\section{Analisis Inferensia}

\section{Uji Independensi}

Langkah awal yang harus dilakukan ialah menguji hubungan antara tiap-tiap variabel bebas dengan variabel usia kawin pertama pada WPK 15-24 tahun dengan menggunakan uji chisquare. Dengan menggunakan tingkat signifikansi 5 persen, dinyatakan menolak hipotesis nol jika nilai $p$-value dari pearson chi-square yang diperolah kurang dari tingkat signifikansi 5 persen $(p$-value $<0,05)$. Pada Lampiran 4. terlihat bahwa seluruh variabel bebas memiliki nilai p-value kurang dari 0,05, artinya bahwa seluruh variabel bebas memiliki hubungan yang signifikan terhadap status perkawinan usia anak pada WPK 15-24 tahun di Indonesia. Dengan demikian, maka keseluruhan variabel bebas tersebut dapat di analisis dengan manggunakan analisis regresi logistik.

\section{Uji Simultan}

Berdasarkan hasil yang diperoleh pada Persamaan 2. dapat dilihat nilai statistik uji G yang mengikuti distribusi Chi-square dengan derajat bebas 15 sebesar 1108,697 dan nilai signifikansi sebesar 0,000 (Lampiran 5). Jika nilai signifikansi tersebut dibandingkan dengan tingkat signifikansi yang digunakan dalam penelitian ini yaitu 5 persen, maka dapat diambil kesimpulan bahwa hipotestis nol ditolak. Artinya minimal terdapat satu variabel bebas yang mampu menjelaskan status perkawinan usia anak pada WPK usia 15-24 tahun di Indonesia.

\section{Uji Parsial}

Tahap selanjutnya yaitu menguji signifikansi tiap-tiap variabel bebas secara parsial terhadap variabel tak bebas nya menggunakan Persamaan 3. Berdasarkan hasil pada Lampiran 9. Variabel bebas daerah tempat tinggal, status dan jenis pekerjaan wanita, tingkat pendidikan wanita, tingkat pendidikan orang tua, usia kawin pertama orang tua dan status kemiskinan signifikan pada tingkat signifikansi 5 persen. Artinya tiap-tiap variabel bebas tersebut mampu secara parsial memengaruhi serta menjelaskan variabel tak bebasnya yaitu status perkawinan anak pada WPK 15-24 tahun di Indonesia. Berdasarkan hasil pengujian tersebut diperoleh bentuk persamaan model sebagai berikut.

$\hat{g}(x)=-2,315^{*}+0,173 \mathrm{X} 1$ (pedesaan)* $+0,188 \mathrm{X} 2$ (Tidak bekerja) $^{*}+0,277 \mathrm{X} 2$ (Informal)* $^{*}$

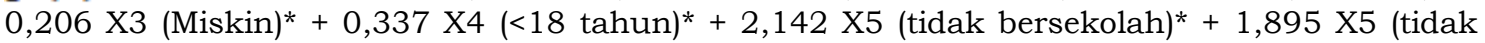
lulus SD)* + 1,809 X5 (Lulus SD)* + 2,528 X5 (tidak lulus SMP)* + 1,719 X5 (Lulus SMP)* + 2,268 X5 (Tidak Lulus SMA)* - 0,005 X5 (Lulus SMA) - 0,135 X6 (tidak bersekolah) - 0,314 X6 (SD)* - 0,090 X6 (SMP)

* signifikan pada tingkat signifikansi 5 persen.

\section{Uji Kelayakan Model (Goodness of fit)}

Berdasarkan Lampiran 6 nilai Chi-square yang diperoleh dari Persamaan 4 sebesar 3,188 atau nilai p-value sebesar 0,922 pada step terakhirnya menunjukan bahwa hipotesis nol gagal ditolak dengan tingkat signifikansi yang digunakan dalam penelitian ini yaitu 5 persen. Hasil tersebut menunjukkan bahwa model regresi yang diperoleh sudah cocok/fit dengan data yang digunakan atau tidak ada perbedaan signifikan antara model dengan nilai observasinya. 


\section{Classification Table}

Sesuai dengan hasil pada lampiran 8. Overal percentage correct pada step terakhir dalam penelitian ini sebesar 71,9 persen. Nilai tersebut artinya model yang diperoleh secara keseluruhan mampu memprediksi status perkawinan usia anak pada WPK 15-24 tahun dengan baik, yaitu sebesar 71,9 persen. Selain itu, hasil yang dipaparkan pada lampiran 8 menunjukkan bahwa model mampu mengklasifikasikan 90,5 persen wanita pernah kawin usia 15-24 tahun memiliki usia kawin pertama diatas usia anak dengan tepat dan sebesar 28,3 persen wanita pernah kawin usia 15-24 tahun memiliki usia kawin pertama pada usia anak dengan tepat.

\section{Odds Ratio}

Besar pengaruh dari tiap-tiap variabel bebas terhadap variabel usia kawin pertama pada wanita pernah kawin 15-24 tahun dapat dilihat dengan odds ratio yang merupakan nilai dari $\exp (\widehat{\beta})$. Berikut interpretasi dari $\hat{\beta}$ pada lampiran 9 .

1. Nilai slope intercept dari model

Nilai intercept sebesar -2,315 artinya ketika variabel bebas lainnya bernilai 0, atau ketika wanita pernah kawin 15-24 tahun tersebut tinggal di perkotaan, bekerja di sektor formal, berpendidikan diatas SMA, pendidikan orang tua nya minimal SMA, usia kawin pertama orang tua nya diatas atau sama dengan 18 tahun dan tidak miskin memiliki peluang untuk melakukan pekawinan pada usia anak $(\mathrm{Y}=1)$ ialah sebesar $[\exp (-2,315)] /[1+\exp (-2,315)]=$ 0,0899 atau 8,99 persen.

\section{Daerah tempat tinggal}

Daerah tempat tinggal berpengaruh signifikan terhadap perkawinan usia anak di Indonesia. WPK 15-24 tahun yang tinggal didaerah pedesaan berpengaruh positif terhadap praktek perkawinan pada usia anak dengan koefisien sebesar 0,173. Artinya WPK 15-24 tahun yang berdomisili di daerah perdesaan cenderung untuk melakukan perkawinan pada usia anak sebesar 1,189 kali dibandingkan WPK 15-24 tahun yang tinggal di daerah perkotaan. Hasil tersebut sesuai dengan penelitian yang dilakukan oleh Pujihasvuty (2011) menyatakan bahwa umur kawin pertama di daerah perkotaan lebih tinggi daripada di perdesaan.

3. Status dan jenis pekerjaan wanita

Status dan jenis pekerjaan wanita berpengaruh signifikan terhadap perkawinan usia anak di Indonesia. WPK usia 15-24 tahun yang tidak bekerja berpengaruh positif terhadap praktek perkawinan pada usia anak dengan koefisien sebesar 0,188. Artinya wanita yang yang tidak mempunyai pekerjaan cenderung untuk melangsungkan perkawinan sebelum usia 18 tahun sebesar 1,207 kali dibandingkan wanita yang bekerja disektor formal. Sementara itu, wanita yang bekerja di bidang informal cenderung untuk melangsungkan perkawinan sebelum usia 18 tahun sebesar 1,319 kali dibandingkan wanita yang bekerja disektor formal.

Hal ini sejalan dengan penelitian yang dilakukan oleh Zai (2010) yang mengungkapkan bahwa terdapat hubungan antara pekerjaan responden dengan kejadian pernikahan dini. Seorang wanita yang tidak memiliki status pekerjaan cenderung melakukan pernikahan dini karena ketidakmampuan untuk membiayai kebutuhan hidup.

International Center for Research on Women (2016) juga menyatakan bahwa perkawinan pada usia anak berpengaruh terhadap partisipasi angkatan kerja. Anak perempuan yang menikah pada usia dini cenderung dikeluarkan dari sekolah dan menyebabkan partisipasi mereka dalam pasar tenaga kerja formal lebih rendah dan menerima pendapatan yang lebih rendah sepanjang waktu.

4. Status kemiskinan

Status ekonomi WPK 15-24 tahun berpengaruh signifikan terhadap pernikahan usia anak di Indonesia. WPK usia 15-24 tahun yang mempunyai status ekonomi miskin berpengaruh positif terhadap praktek pernikahan pada usia anak dengan koefisien sebesar 0,206. Artinya WPK usia 15-24 tahun yang status ekonominya miskin cenderung untuk melakukan perkawinan pada usia anak sebesar 1,229 kali dibandingkan WPK usia 15-24 tahun yang status ekonominya tidak miskin.

Berdasarkan hasil tersebut wanita yang menikah pada usia anak cenderung berasal dari rumah tangga miskin karena pendapatan perkapita yang diterima masih tergolong rendah 
sehingga belum cukup untuk melewati batas minimum dari Garis kemiskinan. Hal ini sejalan dengan penelitian Marshan (2010) yang menemukan adanya hubungan negatif antara perkawinan usia anak dan pengeluaran per kapita, peningkatan pengeluaran per kapita terbukti dapat menurunkan kemungkinan terjadinya perkawinan usia anak.

5. Usia perkawinan pertama orang tua

Hasil dari penelitian menunjukkan bahwa usia kawin pertama orang tua berpengaruh terhadap usia kawin pertama anak perempuannya. Pada Lampiran 9. terlihat bahwa orang tua yang dulunya menikah sebelum usia 18 tahun berpengaruh positif terhadap usia kawin pertama anaknya dengan koefisien sebesar 0,337. Artinya orang tua yang dulunya menikah sebelum usia 18 cenderung untuk menikahkan anak perempuannya sebelum usia 18 tahun juga sebesar 1,401 kali dibandingkan orang tua yang dulunya menikah lebih dari usia 18 tahun.

Dengan demikian dapat dilihat bahwa anak perempuan cenderung meniru perilaku atau kebiasaan dari orang tua nya, termasuk dalam kasus ini usia perkawinan atau budaya menikah pada usia anak yang dilakukan oleh orang tua nya. Hal ini sejalan dengan penelitian (Briawan \& Herawati, 2008) yang menyatakan bahwa perilaku orang tua didalam sebuah keluarga akan dilihat dan ditiru oleh anaknya dalam jangka waktu tertentu.

6. Pendidikan wanita kawin 15-24 tahun

Pendidikan WPK 15-24 tahun berpengaruh signifikan terhadap maraknya praktek perkawinan usia anak di Indonesia. WPK 15-24 tahun yang pendidikan terakhirnya tidak lulus SMP berpengaruh terhadap praktek perkawinan pada usia anak dengan koefisien sebesar 2,528. Artinya WPK 15-24 tahun yang pendidikan terakhirnya tidak lulus SMP cenderung untuk melakukan perkawinan pada usia anak sebesar 12,523 kali dibandingkan WPK 15-24 tahun yang pendidikan terakhirnya diatas SMA. Kemudian, WPK 15-24 tahun yang pendidikan terakhirnya lulus SMA berpengaruh terhadap praktek perkawinan pada usia anak dengan koefisien sebesar - 0,005. Artinya WPK 15-24 tahun yang pendidikan terakhirnya lulus SMA cenderung untuk melakukan perkawinan pada usia anak sebesar 0,995 kali dibandingkan WPK 15-24 tahun yang pendidikan terakhirnya diatas SMA. Sementara itu, ketika WPK 15-24 tahun tersebut tidak mengenyam pendidikan atau tidak bersekolah cenderung untuk melakukan perkawinan pertama kali sebelum usia 18 tahun sebesar 8,513 kali dibandingkan WPK 15-24 tahun yang pendidikan terakhirnya diatas SMA. Hal ini menyatakan bahwa WPK usia 15-24 tahun yang tidak bersekolah atau tidak lulus pada tiap jenjang pendidikannya memiliki kecenderungan yang lebih besar untuk melakukan perkawinan pada usia anak dibandingkan wanita yang lulus di tiap jenjang pendidikannya.

Hasil tersebut sesuai dengan penelitian yang dilakukan oleh Dewi Candraningrum (2016) yang menyatakan bahwa anak perempuan yang berpendidikan rendah dan drop-out dari sekolah umumnya lebih rentan menikah pada usia anak dari pada yang berpendidikan menengah dan tinggi.

\section{Pendidikan Orang tua}

Hasil pengolahan menunjukkan bahwa pendidikan orang tua berpengaruh terhadap usia kawin pertama anak perempuannya. Pada lampiran 9. terlihat bahwa orang tua yang pendidikan terakhirnya sekolah dasar berpengaruh terhadap usia kawin pertama anaknya dengan koefisien sebesar -0,314. Artinya orang tua yang pendidikan terakhirnya sekolah dasar cenderung untuk menikahkan anak perempuannya sebelum usia 18 tahun sebesar 0,731 kali dibandingkan orang tua yang pendidikan terakhirnya minimal SMA. Sementara itu, ketika orang tua tersebut tidak mengenyam pendidikan atau tidak bersekolah cenderung untuk menikahkan anak perempuannya sebelum usia 18 tahun sebesar 0,874 kali dibandingkan orang tua yang pendidikan terakhirnya minimal SMA.

Hal ini bertentangan dengan penelitian (Jennifer Parsons et al,2015) yang menyatakan bahwa pendidikan orang tua memengaruhi usia kawin pertama anak perempuannya. Anak perempuan yang pendidikan ibunya rendah lebih mungkin untuk menikah lebih awal. Lain halnya dengan penelitian yang dilakukan oleh Jennifer parstons, hasil dari penelitian ini sejalan dengan penelitian yang dilakukan oleh Riski Anisa (2015) yang mendapati hasil bahwa semakin tinggi pendidikan orang tua yang di tempuh, semakin positif sikap orang tua terhadap pernikahan anaknya di bawah usia 20 tahun. Hal ini disebabkan oleh beberapa alasan, yaitu adanya perasaan takut orang tua akan ditinggal anak sekolah atau bekerja jauh dari rumah. Alasan lainnya adalah kebanyakan ukuran tubuh anak perempuannya sudah cukup besar sehingga orang tua merasa malu dan menganggap sudah cukup untuk perempuan menikah 


\section{Ade Widiantara dkk.}

walaupun usia belum 20 tahun serta perasaan takut pada anaknya berbuat macam-macam dan membuat malu keluarga, maka lebih baik dinikahkan.

\section{KESIMPULAN}

Berdasarkan hasil analisis penelitian ini,maka peniliti mengambil beberapa kesimpulan sebagai berikut :

1. Lebih seperempat dari seluruh WPK berusia 15-24 tahun menikah pada usia anak. Artinya terdapat 1 dari 4 wanita melangsungkan perkawinan sebelum usia 18 tahun. Diantara WPK berusia 15-24 tahun yang melakukan perkawinan pada usia anak, mereka yang berdomisili di daerah pedesaan lebih tinggi dibandingkan perkotaan dan umumnya terjadi pada keluarga yang miskin. Persentase perkawinan anak pada WPK berusia 15-24 tahun yang putus sekolah dan atau tidak bersekolah lebih tinggi dari pada mereka yang menamatkan sekolahnya. Begitu pula WPK yang bekerja pada sektor informal memiliki persentase perkawinan anak lebih tinggi dari pada mereka yang bekerja di sektor formal dan atau tidak memiliki pekerjaan. Kasus perkawinan anak juga banyak terjadi pada WPK yang usia kawin pertama orang tuanya pada usia anak dan berpendidikan rendah. Orang tua yang tidak bersekolah kemudian menikahkan anaknya sebelum usia 18 tahun lebih banyak dari pada orang tua yang bersekolah.

2. Faktor-faktor yang memengaruhi keputusan untuk melakukan perkawinan anak pada wanita pernah kawin berusia 15-49 tahun di Indonesia, yaitu variabel daerah domisili tempat tinggal, status bekerja dan jenis pekerjaan wanita, tingkat pendidikan wanita, tingkat pendidikan orang tua, usia kawin pertama orang tua dan status kemiskinan.

3. Kecenderungan untuk melangsungkan pernikahan pada usia anak lebih besar terjadi pada wanita kawin yang berasal dari rumah tangga miskin, bertempat tinggal di daerah pedesaan, bekerja pada sektor informal, pendidikan terakhirnya tidak lulus SMP, memiliki orang tua yang pendidikan terakhirnya SMA atau diatasnya dan dahulunya juga menikah pada usia anak.

\section{SARAN}

Adapun saran yang dapat disusun berdasarkan hasil penelitian, yaitu sebagai berikut :

1. Pemerintah perlu melakukan revisi terhadap UU No. 1 tahun 1974 dengan meningkatkan batas minimal usia diperbolehkan menikah menjadi 18 tahun untuk perempuan dan 21 tahun untuk laki-laki.

2. Pemerintah harus lebih menggencarkan program-program seperti wajib belajar 12 tahun, sosialisasi kesehatan reproduksi terkait ciri fisik, psikis optimal dan kesiapan mental untuk melangsungkan pernikahan serta dampak negatif yang mungkin terjadi akibat melangsungkan pernikahan pada usia anak. Program-program tersebut penting untuk segera direalisasikan terutama pada masyarakat ekonomi lemah dan tinggal di pedesaan, serta pada orang tua yang berpendidikan rendah dimana wawasan terkait dampak negatif akibat perkawinan usia anak dan kesehatan reproduksi masih sangat kurang. Sehingga dengan terealisasinya program-program tersebut diharapkan mampu menurunkan jumlah kasus perkawinan usia anak di masyarakat Indonesia.

3. Bagi penelitian selanjutnya agar dapat menambah variabel sosial dan demografi lainnya seperti pengetahuan tentang kesehatan repoduksi, agama, dan motif melakukan perkawinan.

\section{DAFTAR PUSTAKA}

Agresti, A. (2000). Categorical Data Analysis (2nd ed). New Yok: John Wiley \& Sons.

Aulia Imawati, dkk (2011). Analisis Regresi Logistik Biner Pada Faktor-Faktor Yang Mempengaruhi Wanita Menikah Muda Di Provinsi Jawa Timur. Surabaya. Laporan Penelitian. Institut Teknologi Surabaya.

Anisa Riski, et al. (September 2015). Intensi Orang Tua dalam Pengambilan Keputusan untuk Menikahkan Anak Perempuan di Bawah Usia 20 Tahun di Kecamatan Pakem Kabupaten Bondowoso. e-Jurnal Kesehatan, Vol.3 No.3. 
Badan Pusat Statistik. (2017). Indikator kesejahteraan Rakyat 2017. Jakarta: BPS

Badan Pusat Statistik. (2017). Buku Pedoman Pencacahan Susenas 2017. Jakarta: BPS

BKKBN \& BPS. (2013). Survei Demografi dan Kesehatan Indonesia 2012. Jakarta: BPS.

BPS \& UNICEF. (2016). Laporan analisis data perkawinan usia anak di Indonesia 2013 dan 2015. Jakarta.

Briawan, D \& Herawati, T. (2008). Peran Stimulasi Orangtua terhadap Perkembangan Anak Balita Keluarga Miskin. Jurnal Ilmu Keluarga \& Konsumen, vol 01 No.01 63-76

Council of Foreign Relations. 2013. "Child Marriage". Retrieved from https://www.cfr.org/interactives/child-marriage?cid=otr_marketing_usechild_ marriage_Infoguide\%2523!/\#!/. Diakses tanggal 28 Desember 2017.

Dewi Candraningrum, dkk (2016). Takut akan Zina, Pendidikan Rendah, dan Kemiskinan: Status Anak Perempuan dalam Pernikahan Anak di Sukabumi Jawa Barat. Jurnal Perempuan, Vol.21 No.1 h.150.

Hosmer, D. W. dan Lemeshow, S. 2000. Applied Logistic Regression (2 ${ }^{\text {nd }}$ ed). New York: John Wiley and Son

ICRW (2016). Taking Action To Address Child Marriage: The Role Of Different Sectors. Washington, DC: ICRW. Available at: https://www.girlsnotbrides.org/resource-centre/child-marriagebrief-role-of-sectors/. Diakses tanggal 25 Mei 2018.

Jennifer Parsons, Jeffrey Edmeades, Aslihan Kes, Suzanne Petroni, Maggie Sexton \& Quentin Wodon (2015). Economic Impacts of Child Marriage: A Review of the Literature. The Review of Faith \& International Affairs, 13:3, 12-22, DOI: 10.1080/15570274.2015.1075757.

Konvensi Hak Anak, Pasal 28 dan 31, h.8-9, dalam BPS-Unicef, Kemajuan yang Tertunda: Analisis Data Perkawinan Usia Anak di Indonesia. (Jakarta: 2016), h.9.

Marshan, J., Rakhmadi, F., dan Rizky, M. 2010 "Prevalence of Child Marriage and Its Determinant among Young Woman in Indonesia". Jakarta: SMERU Research Institute

Minja Kim choe et al (2001). Early Marriage and childbearing in Indonesia and Nepal. East-West Center Working Papers, No 108-15.

Pujihasvuty, R. (2011). Pola Kawin dan Fertilitas Wanita Pasangan Usia Subur di Indonesia. Jurnal ilmiah puslitbang KB dan KS, Vol. 05 No. 1, Hal. 4355.

Republik Indonesia. 1974. Undang-Undang No. 1 Tahun 1974 tentang Perkawinan. Lembaran Negara RI Tahun 1974, No. 1. Sekretariat Negara. Jakarta.

Republik Indonesia. 2014. Undang-Undang No. 35 Tahun 2014 tentang Perubahan Atas UndangUndang Nomor 23 Tahun 2002 Tentang Perlindungan Anak. Lembaran Negara RI Tahun 2014, No. 5606. Sekretariat Negara. Jakarta.

Sa'dan, Masthuriyah. (2016). Akulturasi Hukum Islam \& Hukum Adat Perkawinan Matrilokal Di Madura. Jurnal Kebudayaan Islam, Vol. 14 No. 1, 129-138.

Zai, F. 2010. Faktor-faktor yang berhubungan dengan pernikahan dini pada remaja di Indonesia. Jakarta: Fakultas Ilmu Kesehatan Universitas Indonesia. 